\title{
Sikap dan Respon Anak PAUD dalam Mengenal Metamorfosis Serangga melalui Media Animasi
}

\author{
Ajeng Muliasari'1, Linda ${ }^{2} \bowtie$ \\ Pendidikan Guru Sekolah Dasar, Sekolah Tinggi Keguruan dan Ilmu Pendidikan Syekh \\ Mansur (1) \\ Pendidikan Matematika, Sekolah Tinggi Keguruan dan Ilmu Pendidikan Syekh Mansur (2) \\ DOI: $\underline{\text { 10.31004/obsesi.v5i2.776 }}$
}

\begin{abstract}
Abstrak
Penelitian ini bertujuan untuk mengetahui sikap dan respon anak Pendidikan Anak Usia Dini (PAUD) dalam mengenal metamorfosis serangga, yang dalam penelitian ini akan mengenalkan serangga jenis Kupu-Kupu dan Belalang menggunakan media animasi berbasis Computer Assisted Instruction atau CAI. Keunggulan dari media animasi berbasis Computer Assisted Instruction atau CAI ini dapat dioperasikan secara mandiri oleh anak dan anak daoat memilih metamorphosis mana yang ingin mereka pelajari. Metode penelitian ini menggunakan pendekatan kualitatif deskriptif dengan tehnik triangulasi data untuk dapat menarik hasil analisis dari pemberian media animasi berbasis CAI yang sudah dilakukan oleh guru. Hasil analisis dari penelitian ini adalah terdapat progress sikap dan respon yang bagus ditunjukkan dengan lebih responsivenya sikap anak PAUD terhadap pelajaran, terhadap guru, dan pada proses pembelajarannya. Progress juga ini dapat ditunjukkan dari antusias anak saat belajar, banyak mengeluarkan pendapat dan pertanyaan.
\end{abstract}

Kata kunci: sikap; respon; media; animasi

\begin{abstract}
The study is to identify the attitudes and responses of children at an early age in child education (paud) in recognition of the insect's metamorphosis, in which it will introduce insect kinds of butterflies and locusts using computer-based animation assisted assisted reporting or CAI. The advantages of this computer-based animated media assisted assisted or CAI can be operated independently by children and children daoat choosing which metamorphosis they would like to learn. This method of research USES a descriptive qualitative approach with data to pull up analysis from the CAI media that the teachers have already done. Analysis of the study is that there is a good progress and response indicated by more responsiveness of the child's attitude toward the lesson, toward the teacher, and in the process of learning. Progress too can be shown by a enthusiastic child in his study, a lot of opinions and question.
\end{abstract}

Keywords: attitude; response; media; animation/

Copyright (c) 2020 Ajeng Muliasari, Linda

$\triangle$ Corresponding author :

Email Address : muliasariajeng1@gmail.com ( Pandeglang, Indonesia )

Received 18 September 2020, Accepted 30 September 2020, Published 3 Oktober 2020 


\section{PENDAHULUAN}

Media pembelajaran merupakan unsur terikat dalam berjalannya proses pembelajaran, tanpa adanya media pembelajaran tentunya akan bersifat pasif dan membosankan bagi anak. Seiring dengan kemajuan IPTEK, pengembangan media pembelajaran menjadi salah satu efek dari kemajuan IPTEK ini. Para pakar pendidikan di Indonesia pun sudah banyak melakukan penelitian dan pembaharuan terkait pengembangan media pembelajaran yang efektif dan terpadu. Hal ini serupa dengan yang dituliskan oleh (Lalu Teguh Jiwandanu, n.d.) dalam web yang dimilikinya bahwa pemanfaatan media dalam lingkup TK/PAUD merupakan salah satu dari sekian banyak masalah dalam pembelajaran di sekolah. Permasalahan ini relevan dengan bukti empiris yang terjadi di lapangan khususnya dalam penggunaan tekhnologi atau pembelajaran berbasis multimedia melalui pendekatan media animasi bagi anak usia dini.

Pembelajaran berbasis Computer Assisted Instruction atau CAI bagi anak usia dini, penerapannya dapat melalui bentuk media animasi. Dalam hal ini peneliti mengembangkan media animasi metamorphosis serangga untuk anak usia dini. Konsep media animasi atau animasi sendiri sangat dekat dengan anak PAUD, dimana seperti yang ditulis dalam penelitian (Wang Di, 2012) menyebutkan, penciptaan animasi adalah seni komprehensif waktu yang melampaui visi dan audisi dan lahir dengan gabungan seni lain. teknologi digital elektronik saat ini menggabungkan dari animasi multimedia dan pencampuran antara animasi dua dimensi tradisional (lukisan cat minyak, potongan kertas, lukisan Cina, lukisan pernis, gambar garis, cetak blok, patung stereo) dengan animasi digital tiga dimensi yang semakin populer, dari animasi diam hingga animasi suara, dari animasi realistis dan konkret hingga animasi abstrak semi-realistis dan murni. Hal ini dapat disimpulkam bahwa dari sebelum animasi ber-metamorfosis ke animasi berbasis multimedia, sejak masih menggunakan animasi dua dimensipun, anak-anak usia dini sudah sangat dekat dengan animasi.

Dalam penelitian yang dilakukan oleh (Panjaitan et al., 2020) menyatakan masih terbatasnya penggunaan media animasi dalam proses pembelajaran pada setiap mata pelajaran, terbatasnya penggunaan media animasi karena memerlukan keahlian khusus untuk membuat media tersebut. Selain itu pengembangan pembelajaran berbasis multimedia pun seperti yang dilakukan oleh (Himmah Taulany, Lisa Virdinarti Putra, 2020) pada penelitiannya menyatakan Pendidik PAUD sudah banyak memanfaatkan media-media konkret sesuai karakteristik anak usia dini yang lebih baik belajar dengan situasi dan media yang konkret karena tidak semua media digital mempunyai dampak negatif. Dengan penggunaan yang bijak, manfaat media digital seperti android atau (pembelajaran multimedia) lainnya juga dapat memberikan pembelajaran yang menyenangkan bagi anak usia dini. Tentu saja program atau aplikasi yang digunakan harus disesuaikan dengan kebutuhan belajar anak usia dini.

Sejalan dengan itu (Nasution et al., 2020) menyatakan pembelajaran berbasis ICT atau penggunaan media berbasis teknologi, pada era millenial ini anak tumbuh dan berkembang dengan internet, ponsel dan bentuk-bentuk lain dari ICT atau penggunaan media berbasis teknologi atau interaksi digital sehingga perlu melibatkan ICT kedalam kegiatan pembelajaran anak. Pembelajaran ICT yang digunakan adalah pembelajaran ICT berbasis interaktif dan pembelajaran ICT berbasis non interaktif. Hal ini juga yang dirasakan oleh beberapa guu di TKIT Irsyadul I'Bad yang masih belum mahir menggunakan ICT atau pengembangan pelajaran dengan teknologi yang mengikuti kebutuhan anak, pembelajaran dan pelatihan masih perlu diterapkan oleh pihak sekolah untuk melatih kemampuan guru TKIT Irsyadul I’Bad.

Pentingnya pembelajaran menggunakan tekhnologi pun diperkuat oleh (Pekka Mertala, 2019) yang menyebutkan konteks integrasi teknologi untuk memberikan pemahaman yang lebih bernuansa tentang keragaman dan peran keyakinan guru tentang 
integrasi teknologi yang berfokus pada pendidikan anak usia dini (PAUD) sejauh ini, belum ada ulasan tentang keyakinan guru anak usia dini akan penggunaan teknologi di PAUD. Sintesisnya menunjukkan, bahwa pendidikan, sosialisasi, dan perawatan semua memiliki peran yang berarti dalam keyakinan guru terhadap penggunaan teknologi di PAUD. Ini berarti guru dalam lingkup PAUD perlu mengembangkan tekhnologi dalam pembelajaran yang diberikan pada anaknya. Pengembangan sikap dan respon anak dalam pembelajaran dapat dilakukan dengan penggunaan media pembelajaran yang menyenangkan dan mudah diserap bagi anak usia dini, dan pembelajaran media animasi dengan pendekatan multimedia dapat menjadi salah satu solusi yang tepat untuk digunakan.

Pembelajaran yang efektif bagi anak usia dini adalah pembelajaran yang mampu meningkatkan minat anak, hal ini dapat dilihat dari sikap dan respon anak saat belajar. Belajar hanya menggunakan media lisan akan membuat anak PAUD merasa jenuh dan bosan, sehingga menurunkan atensi sikap dan respon dalam pembelajaran. Beberapa penelitian yang telah menggunakan media animasi untuk mengukur respon peserta didik, menunjukkan hasil yang efektif, seperti dalam penelitian (sadat, 2019) dalam penelitian ini menghasilkan bahwa pembelajaran menggunakan media video animasi pada materi operasi bilangan bulat memiliki tampilan yang menarik dan menyenangkan karena terdapat gambar, animasi dan suara. Anak juga menyatakan bahwa pembelajaran menggunakan media video animasi ini dapat membantu memahami materi.

Pengenalan mengenai serangga untuk anak usia dini merupakan hal yang penting, karena serangga sangat dekat dengan kehidupan sehari-hari anak, dan anak perlu mengetahui akan konsep pertumbuhan unik dari salah satu jenis mahluk hidup dalam hal ini adalah serangga, dalam jurnal penelitian yang ditulis oleh (Rahman et al., 2018) menjelaskan bahwa urgensi dari perlunya anak PAUD mengetahui metamorphosis serangga adalah berkaitan dengan aspek kognitif juga tentang kebutuhan anak untuk secara aktif didalam lingkungan. Lingkungan yang dimaksud yaitu lingkungan yang berada didekat anak. Seperti yang dijelaskan dalam (Menteri, 2013) tentang Kurikulum 2013 Pendidikan Anak Usia Dini dalam kompetensi Dasar 4.8 yang berbunyi “ Menyajikan berbagai karya yang berhubungan dengan lingkungan alam (hewan, tanaman, cuaca, tanah, air, batubatuan, dll) dalam bentuk gambar, bercerita, bernyanyi dan gerak tubuh" dan diperjelas dalam indikator pencapaian perkembangan anak usia 5-6 tahun yang berbunyi “ Menceritakan perkembangbiakan mahluk hidup". Perkembangan mahluk hidup sangat.

Selain itu sejalan dengan penelitian yang ditulis oleh (James W.Truman, 2019) mengenasi "The Evolution Of Insect Metamorphosis", menyebutkan evolusi metamorfosis serangga adalah salah satu hikayat terpenting dalam sejarah hewan, mengubah artropoda tanah yang kecil dan tidak dikenal menjadi kelompok terestrial yang dominan yang telah secara mendalam membentuk evolusi kehidupan di darat. Hal ini menegaskan bahwa keunikan dari perubahan mahluk hidup yaitu serangga, menjadi pengetahuan dasar penting yang perlu diketahui oleh anak usia dini. Dalam penelitian ini, peneliti akan mengenalkan dua serangga paling dekat dengan anak usia dini, yaitu kupu-kupu dan belalang. Saat peneliti melakukan wawancara sederhana dengan guru di TKIT Irsyadul I'Bad, ditemukan fakta bahwa pengenalan metamorphosis serangga hanya pengenalan sangat dasar sekali, seperti kupu-kupu yang diajarkan adalah (telur - ulat - kepompong- kupu-kupu) tanpa menjelaskan proses dari telur itu dari mana asalnya. Ini menjadi salah satu permasalahan yang perlu disolusikan.

Meninjau dari penelitian yang dilakukan oleh (Nofiadi et al., 2017) Pengenalan metamorfosa kupu-kupu indonesia yang digunakan masih menggunakan media berupa gambar yang terdapat di buku-buku, hal ini dinilai kurang efektif karena hanya dapat dilihat pada gambar mati dan berkesan kaku kurang menarik. Tetapi dengan menggunakan teknologi Animasi diharapkan dalam pembelajaran metamorfosis kupu-kupu dapat lebih menarik, modern dan lebih mudah mendapatkan informasi dalam proses pembelajaran. Animasi ini dibangun dengan menggunakan Adobe flash sebagai media 
desain. Hal ini sejalan dengan yang akan dilakukan oleh penelitian ini, mengenalkan metamorphosis kupu-kupu dengan media animasi berbasis multimedia. Ke-efektifan pengenalan metamorphosis serangga dengan menggunakan media animasi pun dibuktikan dengan jurnal prosiding yang dilakukan oleh (Dhuhita, 2018), dalam jurnal prosiding itu disebutkan pembelajaran mengenal metamorphosis serangga melalui sarana audio visual anak-anak lebih mudah menerima dan mencerna karena belajar tanpa sadar melalui tayangan visual.

Dari hasil observasi awal yang dilakukan peneliti dan anggota peneliti di TKIT Irsyadul I'bad atensi anak saat belajar dilihat dari perkembangan sikap dan respon dalam pembelajaran masih belum stabil, anak terkadang masih belum tertarik dengan proses pembelajaran yang dilakukan. Sikap dan respon anak dalam belajar naik turun. Hal ini terjadi karena anak lebih cenderung fokus dalam belajar saat medianya seperti gadget yang mereka sukai, sedangkan pola pembelajaran anak di TKIT Irsyadul I'bad untuk penggunaan media animasi berbasis Computer Assisted Instruction atau CAI belum pernah digunakan, sedangkan TKIT Irsyadul I'bad merupakan TK yang menjadi role model TK lain di Pandeglang. TKIT Irsyadul I'bad yang terus mengembangkan pengaplikasian media belajar untuk para anak dan memfasiltasi beragam media pembelajaran terkini, membuat peneliti tertarik dan merasa penting untuk membantu mengembangkan media pembelajaran inovatif untuk TKIT Irsyadul I'bad, karena dengan TKIT Irsyadul I'bad membuat gebrakan baru dalam belajar menggunakan media animasi berbasi CAI akan menjadi contoh sekolah TK lain dan kemudian akan ada tindak lanjut berupa tutor sebaya dalam forum khusus guru TK se-Pandeglang. Selain itu di TKIT Irsyadul I'bad sudaah memiliki media seperti beberapa tekhnologi mutakhir (Proyektor,Laptop,dll) yang mendukung pengaplikasian media animasi berbasi CAI ini.

Selain itu media pembelajaran dengan pendekatan media animasi berbasis CAI dalam hal ini untuk mengenal proses metamorphosis serangga dengan anak diikutsertakan langsung menggunakan aplikasinya belum pernah dilakukan oleh TKIT Irsyadul I'bad. Pengenalan materi tentang serangga, diajarkan melalui buku cerita dan miniatur mainan berbentuk serangga. Penggunaan media animasi dalam kegiatan pembelajaran mengenal metamorfosis serangga belum pernah dilakukan dengan alasan ketiadaan materi film dan media animasi yang bisa digunakan untuk kegiatan pembelajaran. Dari latar permasalahan tersebut. Permasalahan yang akan di teliti dalam penelitian ini adalah : 1) Bagaimana sikap anak PAUD dalam pengenalan metamorphosis serangga dengan pembelajaran multimedia melalui pendekatan media animasi? 2) Bagaimana respon anak PAUD dalam pengenalan metamorphosis serangga melalui media animasi?

Dari Permasalahan diatas dapat disimpulkan bahwa tinjauan khusus penelitian ini berfokus mengetahui sikap anak PAUD melalui proses pembelajaran metamorphosis serangga menggunakan media animasi dan mengetahui respons anak PAUD melalui proses pembelajaran metamorphosis serangga menggunakan media animasi sehingga dari hasil penggunaan media animasi tersebut dapat dilakukan analisis sikap dan respons anak dalam pembelajaran mengenal metamorphosis serangga di TKIT Irsyadul'Ibad.

Penilaian respon dan sikap ini pun diukur dari obervasi peneliti dan melalui wawancara tertstuktur dengan anak dan guru menggunakan instrument penelitian. Berdasarkan Uraian tersebut terbentuklah judul penelitian "Sikap Dan Respon Anak PAUD Dalam Mengenal Metamorfosis Serangga Media Animasi".

Berdasarkan table 1 muncullah judul baru "Sikap dan Respon Anak PAUD Dalam Mengenal Metamorfosis Serangga Melalui Media Animasi". Judul ini lahir dari hasil analisis peneliti melalui pengamatan dan penemuan dari beberapa jurnal yang penulis rujuk. Pada poin pertama dari state of the art diatas peneliti menemukan pengembangan pembelajaran anak usia dini dalam mengenal huruf menggunakan multimedia (audio, animasi dan visual serta tombol) agar memudahkan anak yang kesulitan dalam memahami konsep angka dan huruf, hal ini terjadi ka- rena anak sulit membedakan konsep-konsep setiap angka dan 
bentuk-bentuk huruf. Penelitian ini menggunakan metode RnD (Dwanda Putra Lovandri, 2015). Di Poin kedua ditemukan pengembangan pembelajaran multimedia dalam mengenal alfabeth melalui macromedia flash professional dengan antar muka interaktif melalui audio, penelitian ini menggunakan metodologi pengembangan waterfall (Faris Ahmad, 2016).

Poin ketiga ditemukan pengembangan pembelajaran multimedia dengan pendekatakan interaktif dalam mengenal kupu-kupu dengan merancang aplikasi berbasis android, penelitian ini menggunakan metodologi pengembangan waterfall (Eka Septi, 2016). Dan poin terakhir ditemukan pengembangan pembelajaran multimedia dengan pendekatakan interaktif dalam mengenal tajwid melalui gambar, suara dan teks, penelitian ini menggunakan metode pengumpulan data dengan wawancara, observasi dan studi pustaka (Kholis Abdul. Herawati., 2015).

Dari keempat artikel jurnal yang peneliti rujuk, semuanya adalah penelitian pengembangan bahan ajar dengan multimedia, dengan pelaporan pembuatan aplikasinya, sedangkan dalam penelitian ini, peneliti tidak berfokus pada pembuatan dan pelaporan aplikasi yang dirancang dengan memaparkan story board, user interface, maupun flowchart, tetapi berfokus pada analisis sikap dan respon anak PAUD/TK yang akan disajikan secara naratif dengan menggunakan penelitian kualitatif deskriptif melalui tiga tahapan; pra-lapangan, lapangan dan pengolahan data. Tabel 2 merupakan literatur lain yang peneliti gunakan untuk mendukung penelitian ini.

Tabel 2 literatur pendukung penelitian

\begin{tabular}{|c|c|c|c|c|}
\hline No & $\begin{array}{c}\text { Nama } \\
\text { Penulis }\end{array}$ & Jurnal & Judul Penelitian & Temuan \\
\hline 1 & $\begin{array}{l}\text { Lovandri } \\
\text { Dwanda } \\
\text { Putra, } \\
\text { Ishartiwi }\end{array}$ & $\begin{array}{l}\text { Inovasi dan } \\
\text { Tekhnologi } \\
\text { Pendidikan } \\
\text { Vol 2, No } 2 \\
\text { (2015) }\end{array}$ & $\begin{array}{l}\text { Pengembangan } \\
\text { Multimedia } \\
\text { Pembelajaran } \\
\text { Interaktif Mengenal } \\
\text { Angka dan Huruf } \\
\text { Anak Usia Dini }\end{array}$ & $\begin{array}{l}\text { Pada penelitian ini saya menemukan } \\
\text { produk pengembangan pembelajaran } \\
\text { multimedia dengan pendekatan } \\
\text { interaktif melalui computer yang } \\
\text { dilengkapi animasi, audio visual, dan } \\
\text { fungsi tombol untuk memaksimalkan } \\
\text { mengenal angka dan huruf. }\end{array}$ \\
\hline 2. & $\begin{array}{l}\text { Ahmad } \\
\text { Faris, Ade } \\
\text { Fitria }\end{array}$ & $\begin{array}{l}\text { Jurnal Teknik } \\
\text { Komputer BSI } \\
\text { Vol 2, No } 1 \\
(2016)\end{array}$ & $\begin{array}{l}\text { Rancangan } \\
\text { Pembelajaran } \\
\text { Interaktif Alfabeth } \\
\text { Pada Anak Usia } \\
\text { Dini }\end{array}$ & $\begin{array}{l}\text { Pada penelitian ini saya menemukan } \\
\text { produk pengembangan pembelajaran } \\
\text { multimedia dengan pendekatan } \\
\text { interaktif menggunakan Macromedia } \\
\text { Flash Profesional dengan antar muka } \\
\text { yang menarik disertai audio. }\end{array}$ \\
\hline 3. & $\begin{array}{l}\text { Septi Eka, } \\
\text { Herlawati }\end{array}$ & $\begin{array}{l}\text { Jurnal } \\
\text { Informatika } \\
\text { Universitas } \\
\text { Pamulang } \\
\text { Vol. } 2 \text { No.1 } \\
\text { (2016) }\end{array}$ & $\begin{array}{l}\text { Animasi Interaktif } \\
\text { Pengenalan Hewan } \\
\text { Khas Pulau } \\
\text { Indonesia Berbasis } \\
\text { Andorid Pada TK } \\
\text { Kupu-Kupu Mungil } \\
\text { Bekasi }\end{array}$ & $\begin{array}{l}\text { Pada penelitian ini saya menemukan } \\
\text { produk pengembangan pembelajaran } \\
\text { multimedia dengan pendekatan } \\
\text { interaktif dengan merancang sebuah } \\
\text { aplikasi berbasis android dalam } \\
\text { mengenal kupu-kupu. }\end{array}$ \\
\hline 4. & $\begin{array}{l}\text { Abdul } \\
\text { Kholis. } \\
\text { Herawati }\end{array}$ & $\begin{array}{l}\text { Jurnal Teknik } \\
\text { Komputer BSI } \\
\text { Vol. } 1 \text { No.2 } \\
(2015)\end{array}$ & $\begin{array}{l}\text { Animasi Interaktif } \\
\text { Pembelajaran } \\
\text { Tajwid Pada Taman } \\
\text { Qur'an Anak (TQA) } \\
\text { Al- Washilah } \\
\text { Cirebon }\end{array}$ & $\begin{array}{l}\text { Pada penelitian ini saya menemukan } \\
\text { produk pengembangan pembelajaran } \\
\text { multimedia dengan pendekatan } \\
\text { interaktif dalam mengenalkan tajwid } \\
\text { menggunakan gambar, suara, dan } \\
\text { teks. }\end{array}$ \\
\hline
\end{tabular}

\section{Respon Pembelajaran Anak Usia Dini}

Dalam buku yang ditulis oleh (Rakhmat, 2013), repon adalah suatu kegiatan (activity) dari organisme itu bukanlah semata-mata suatu gerakan yang positif, setiap jenis kegiatan (activity) yang ditimbulkan oleh suatu perangsang dapat juga disebut respon. Hal ini dapat 
diartikan bahwa respon merupakan bentuk berupa tanggapan yang dihasilkan dari proses penangkapan dan pengolahan alat indera manusia, proses pengangkapan leg alat indera itu kemudian diolah oleh perasaan yang dirasakan maupun proses berfikir, kemudian terbentuklah sebuah tanggapan.

Respon peserta didik maupun guru terhadap suatu metode atau model yang diterapkan oleh guru pada suatu pembelajaran dapat diketahui saat pembelajaran di kela. Sikap individu terhadap objek berperan sebagai perantara respon dan objek. Hal tersebut dapat dikatakan bahwa respon yang ditunjukkan oleh individu terhadap objek dapat memunculkan sikap individu terhadap objek. Respon peserta didik dapat dilihat dari cara peserta didik menyampaikan pendapat, atau sikap yang ditunjukkan melalui bahasa tubuh terhadap stimulus yang diberikan oleh guru hal ini Menurut Steven M. Chaferespon dalam (Rakhmat, 2013)dibedakan menjadi tiga bagian: Kognitif : yang dimaksud dengan respon kognitif adalah respon yang berkaitan erat dengan pengetahuan keterampilan dan informasi seseorang mengenai sesuatu. Respon ini timbul apabila adanya perubahan terhadap yang dipahami oleh khalayak. Afektif : yang dimaksud dengan respon afektif adalah respon yang berhubungan dengan emosi, sikap, dan menilai seseorang terhadap sesuatu. Konatif (Psikomotorik) : yang dimaksud dengan psikomotorik adalah respon yang berhubungan dengan perilaku nyata yang meliputi tindakan atau kebiasaan

\section{Sikap Pembelajaran Anak Usia Dini}

Sikap merupakan sesuatu yang dipelajari, dan sikap menentukan bagaimana individu bereaksi terhadap situasi ranah afektif berkenaan dengan sikap dan nilai. Beberapa ahli mengatakan bahwa "sikap seseorang dapat diramalkan perubahannya, bila seseorang telah memiliki penguasaan kognitif tingkat tinggi. Ranah afektif berkenaan dengan sikap yang terdiri dari lima aspek yaitu : penerimaan, jawaban atau reaksi, penilaian, organisasi, dan internalisa singkatnya.Afektif adalah reaksi individu terhadap apa yang dilihat atau apa yang sedang terjadi. (Azwar S., 2011)

Secara umum, objek sikap yang perlu dinilai dalam proses pembelajaran adalah: Sikap terhadap materi pelajaran : siswa perlu memiliki sikap positif terhadap mata pelajaran. Dengan sikap positif dalam diri siswa akan tumbuh dan berkembang minat belajar, akan lebih mudah diberi motivasi, dan akan lebih mudah menyerap materi pelajaran yang diajarkan. Oleh karena itu guru perlu menilai tentang sikap siswa terhadap mata pelajaran yang diajarkannya. Sikap terhadap guru / pengajar: siswa perlu memiliki sikap positif terhadap guru. Siswa yang tidak memiliki sikap positif terhadap guru akan cenderung mengabaikan hal-hal yang diajarkan. Dengan demikian, siswa yang memiliki. sikap negative terhadap guru atau pengajar akan sukar menyerap materi pelajaran yang diajarkan oleh guru tersebut. Sikap terhadap proses pembelajaran : siswa juga perlu memiliki sikap positif terhadap proses pembelajaran yang berlangsung. Proses pembelajaran mencakup suasana pembelajaran, strategi, metodologi dan teknik pembelajaran yang digunakan. Proses pembelajaran yang menarik, nyaman dan menyenangkan dapat menumbuhkan motivasi belajar siswa, sehingga dapat mencapai hasil belajar yang maksimal. (Eko Putro Widoyoko, n.d.)

Meski begitu teori lain tentang sikap yang dikemukakan oleh Katz dan Stotland dalam (Sutarjo Adi Susilo, 2014), memandang sikap sebagai kombinasi dari : 1) reaksi atau respons kognitif (respons perceptual dan pernyataan mengenai apa yang diyakini), 2) respon afektif (respons pernyataan perasaan yang menyangkut aspek emosional), dan 3) respon konatif (respons berupa kecenderungan perilaku tertentu sesuai dengan dorongan hati). Dari pandangan ini peneliti mengambil kesimpulan bahwa sikap terkait dengan sebuah kombinasi respons yang tergolong menjadi 3 bagian yang sudah dipaparkan pada teori sebelumnya yaitu, kognitif, afektif, dan konatif, kemudian ke-3 respons ini akan melakukan sebuah reaksi dan dalam pembelajaran akan digolongkan menjadi 3 sikap yang 
dapat peneliti analisis, yaitu sikap terhadap pembelajaran, Sikap terhadap guru / pengajar, dan Sikap terhadap proses pembelajaran.

\section{METODOLOGI}

Penelitian dilaksanakan di TKIT Irsyadul I'bad. Sampel dalam penelitian ini adalah anak dalam kelas "Abu Bakar" pada semester ganjil yang berjumlah 15 orang anak. Dalam penelitian ini, media pembelajaran yang digunakan berupa media animasi yang dirancang disesuaikan dengan kebutuhan kegiatan penelitian yakni membahas mengenai materi mengenal metamorphosis serangga untuk anak PAUD/TK. Media animasi tersebut ditayangkan pada setiap proses kegiatan pembelajaran kemudian dianalisis menggunakan pendekatan kualitatif deskriptif untuk dapat menarik hasil analisis dari pemberian media pembelajaran yang sudah dilakukan oleh guru.

Tempat penelitian adalah di TKIT Irsyadul I'bad, untuk waktu penelitian dibagi kedalam beberapa tahapan. Penelitian awal yaitu observasi awal dilakukan pada bulan November 2019 untuk melakukan analisis, wawancara dan peneliti melihat serta meninjau lokasi dan subyek penelitian. Kemudian tahapan kedua pengambilan data mengenai respon dan kesiapan subyek penelitian dilakukan pada awal semester di tahun 2020 untuk menjajaki dan tetap memantau subyek penelitian. Setelah itu Karena terhambat dengan School From Home peneliti melakukan penelitian saat sekolah mulai memasuki masa New Normal di awal agustus. Peneliti melakukan penelitian selama 1 bulan karena aturan yang berlaku guru diperbolehkan Home Visit seminggu sekali dengan pembagian 3 kelompok maka peneliti melakukan penelitian setiap hari senin dengan 4-6 orang anak.

Subyek penelitian adalah anak kelas kelas "Abu Bakar" pada semester ganjil yang berjumlah 15 Orang, yang akan peneliti jadikan subyek utama dalam menganalisis bagaimana sikap dan respon para anak ini terhadap pembelajaran media animasi metamorphosis serangga. Pemilohan subyek penelitian didasari dari hasil observasi awal yang sudah peneliti lakukan, dan mendapat izin dari kepala sekolah untuk menjadikan kelas "Abu Bakar" sebagai subyek penelitian.

Aplikasi media animasi yang digunakan adalah aplikasi yang dibuat dalam penelitian Pembangunan Aplikasi Pembelajaran Metamorfosis Serangga Berbasis Multimedia yang dibuat oleh (Maulana, 2018). Aplikasi ini dibuat dan dikembangkan dengan menggunakan Adobe Flash. Aplikasi ini menggunakan metode teknologi berbasis komputer dalam pembelajaran dikenal sebagai Computer Assisted Instruction (CAI). CAI merupakan pengembangan daripada teknologi informasi terpadu yaitu komunikasi (interaktif), audio, video, penampilan citra (image) yang dikemas dengan sebutan teknologi multimedia. CAI mencakup penggunaan komputer yang berhubungan secara langsung dengan anak maupun pendidik,

Adapun tahapan penelitian yang dilakukan oleh peneliti sesuai dengan gambar 1 Memilih Topik Kajian dengan tahapan pertama menentukan topik kajian secara empirik maksudnya adalah dapat berangkat dari permasalahan dalam lingkup obyek yang diteliti yang sedang terus berlangsung dan bisa diamati serta diverifikasi secara nyata pada saat berlangsungnya penelitian. Instrumentasi, tahapan instrumentasi yang dimaksud dengan ini adalah Instrumen penelitian kualitatif adalah "human instrument" atau manusia sebagai informan maupun yang mencari data dan instrumen utama penelitian kualitatif adalah peneliti itu sendiri sebagai pengumpul data (instrumen). Peneliti terjun langsung ke lapangan untuk mengumpulkan informasi dengan terlebih dahulu sudah memiliki pedoman yang akan dijadikan alat bantu mengumpulkan data. Pedoman tersebut dikembangkan dari kategori/sub kategori yang akan dicari data lapangannya dengan menggunakan teknik berupa kegiatan: observasi, partisipasi, wawancara, dokumentasi. Pelaksanaan Penelitian, tahapan pelaksanaan penelitian dilakukan agar peneliti dapat memperoleh data yang diinginkan, dengan mempersiapkan diri secara fisik, psikologi, maupun mental. Secara fisik peneliti mempersiapkan diri sisi kelengkapan penelitian mulai dari perizinan sampai 
kelengkapan alat-alat bantu. Setelah itu peneliti memilih dan memanfaatkan Informan informan adalah orang-dalam pada latar penelitian. Fungsinya untuk memberikan informasi tentang situasi dan kondisi latar penelitian. Pengolahan Data, tahapan pengolahan data yang pertama adalah reduksi data yang Pertama- tama dilakukan identifikasi terhadap unit/ bagian terkecil dalam suatu data yang memiliki makna bila dikaitkan denag focus dan masalah penelitian.

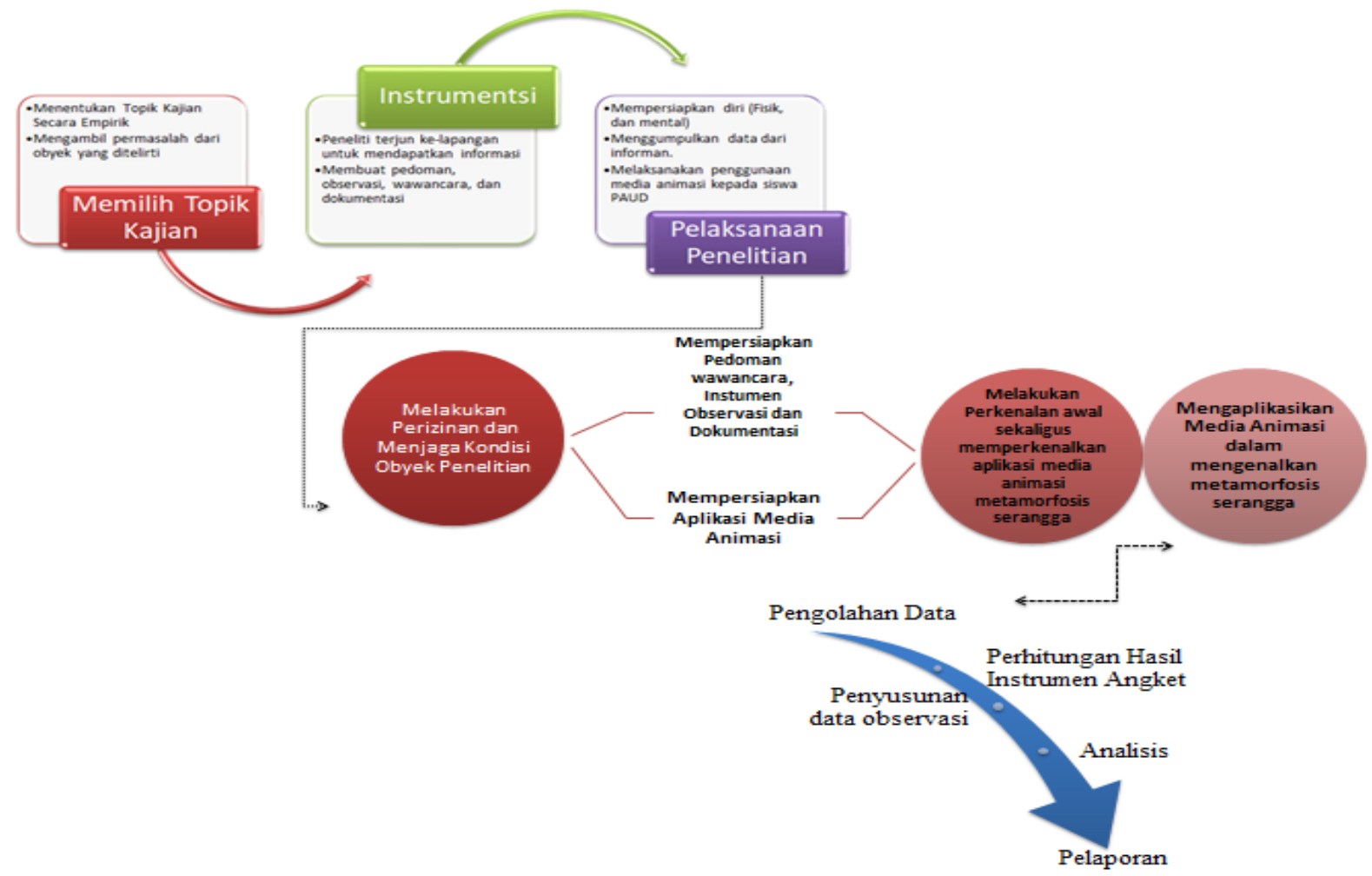

Gambar 1 Bagan Alur Penelitian

\section{HASIL DAN PEMBAHASAN}

Penelitian ini dihasilkan setelah memantau dan menganalisis penggunaan media animasi berbasis CAI dalam mengenalkan proses metamorphosis serangga kepada anak PAUD sebagaimana pada gambar 2, 3 dan 4. Penelitian ini dilakukan setelah peneliti melalkukan perkenalan dan mengetahui respon awal peserta didik melalui zoom meeting, kemudian peneliti melakukan observasi (melalui angket) dan wawancara ke peserta diddik saat melakukan Home Visit dengan guru sebanyak 3 kali untuk 3 kelompok. Peneliti menggunakan pengenalam metamorphosis serangga yang berjenis kupu-kupu dan belalang untuk dikenalkan pada anak PAUD Berikut gambar dari media animasi pengenalan metamorphosis serangga berbasis multimedia yang peneliti gunakan.
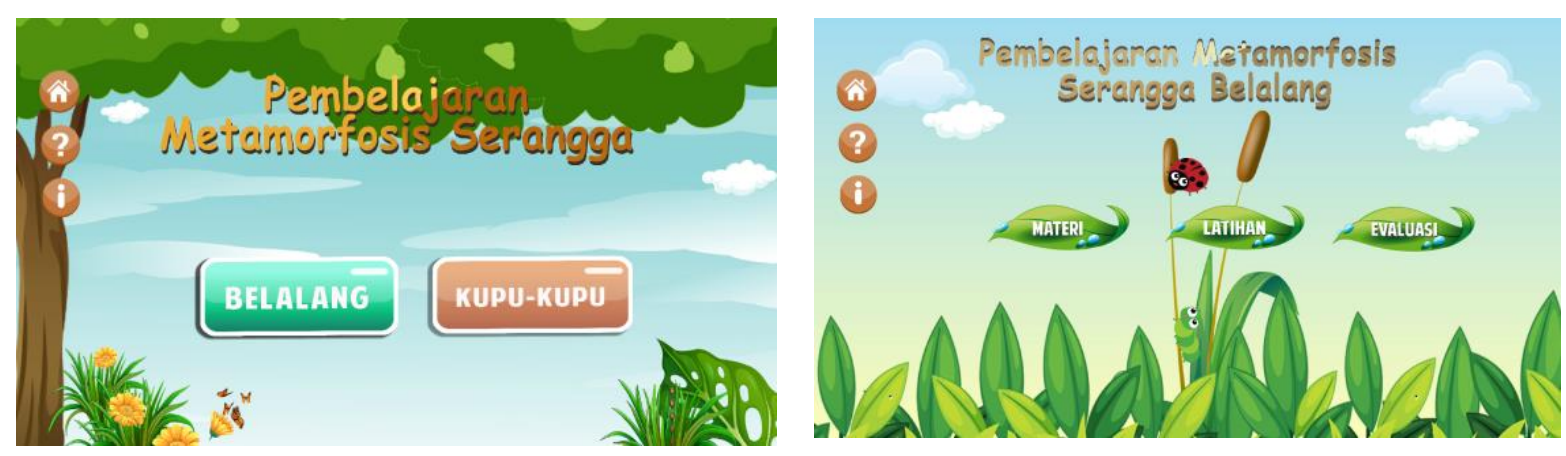

Gambar 2 Cover Depan Aplikasi Media Animasi Pengenalan Metamorfosis Serangga 

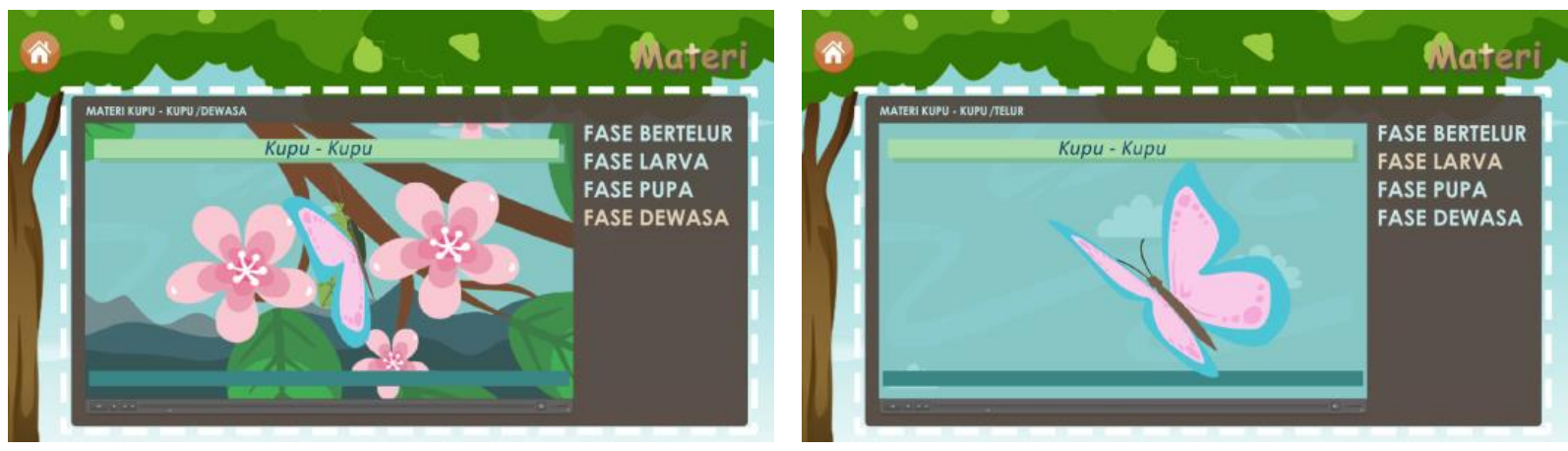

Gambar 3 Materi Metamorfosis kupu-kupu
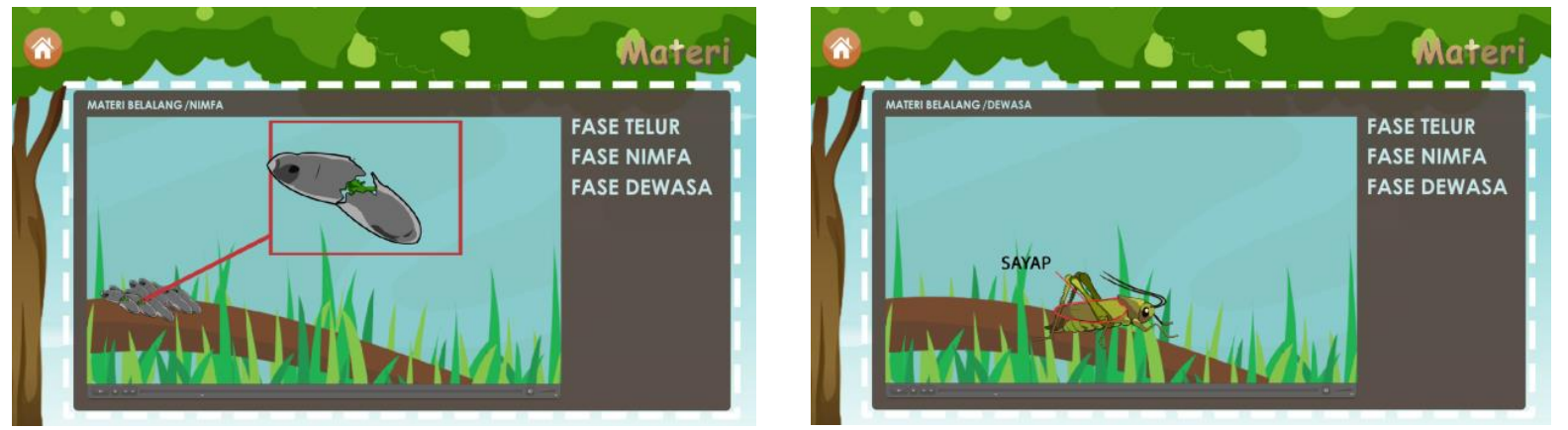

\section{Gambar 4 Materi Metamorfosis Belalang}

Hasil penelitian didapat bukti yng terlihat dari hasil grafik yang terbagi menjadi 2 grafik yaitu sikap dan respon anak. Grafik dari masing- masing variable ini dijelaskan atai di deskripisikan sesuai dengan pembagian kelompok saat home visit.

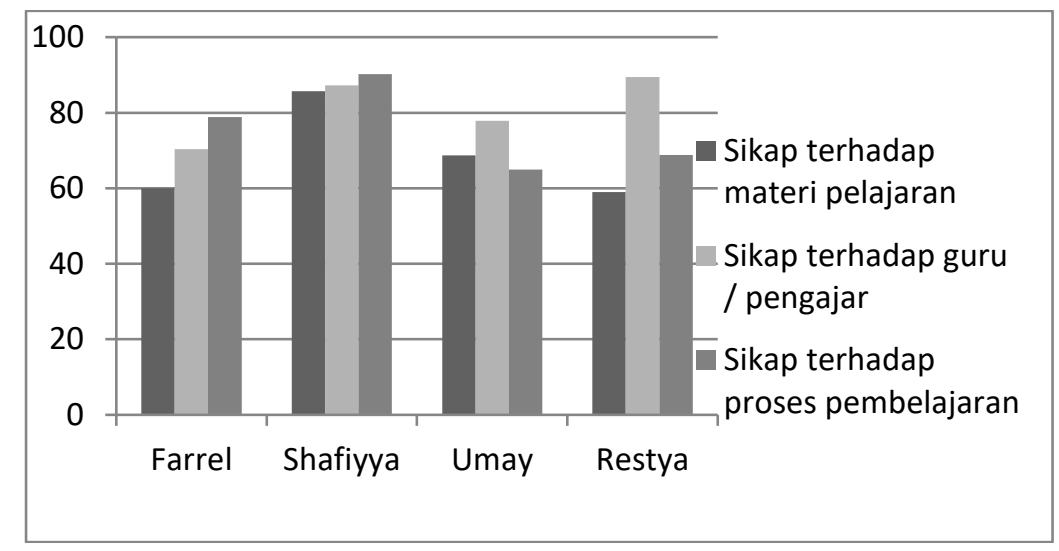

\section{Gambar 5 Grafik Sikap Anak Di Kelompok Ke-1}

Dari hasil grafik 5 dapat dijelaskan empat orang anak di kelas "Abu Bakar" yang bernama Farrel, Shafiyya, Umay dan Restya menunjukkan beberapa sikap terhadap pembelajaran saat diberikan materi pelajaran metamorphosis serangga melalui pembelajaran multimedia berbasis animasi yakni; 1) Sikap terhadap materi pelajaran, Farrel menunjukkan sikap cukup positif karena farrel adalah anak yang pendiam, dia tidak banyak menunjukkan sikap terbuka dengan melihat media pembelajaran yang baru namun farral yang sangat suka media pelajaran dengan warna ini sangat focus memperhatikan dan cukup bisa berkomunikasi dengan aktif. Sama halnya dengan umar dan restya yang memiliki karakter pemalu maka tidak banyak menunjukkan sikap terbuka dengan media pembelajaran yang baru tetapi mereka menunjukkamn sikap posiitf terhadap materi pelajaran dengan cara berbeda misalnya umar sering berbicara sendiri mengatakan kalau 
media yang digunakan menarik saat ia mulai mengoperasikan sendiri medianya, dan restya pun sama sangat pemalu sehingga kurang menujukkan sikap positifnya tetapi langsung memahami cara mengoperasikan medianya ini. Sedangkan Shafiyya paling unggul karena paling menujukkan sikap positif dari antusiasnya saat melihat media yang digunakan. 2) Sikap terhadap guru/ pengajar, Farrel, Shafiyya, Umar dan Restya menunjukkan sikap yang cenderung sama saat belajar metamorphosis serangga melalui pembelajaran multimedia berbasis animasi yaitu sangat fokus dan komunikatif jika diajak komunikasi, bahkan shafiyya terus bertanya banyak hal sebelum guru bertanya, sikap terhadap guru sangat terbuka dan komunikatif. Meski Farrel, Umar dan Restya cukup malu-malu dalam menunjukkan sikap psotf terhadap gurunya. 3) Sikap terhadap proses pembelajaran, Farrel, Shafiyya, Umar dan Restya menunjukkan sikap yang cenderung sedikit berbeda saat belajar metamorphosis serangga melalui pembelajaran multimedia berbasis animasi yaitu : Shafiyya saat proses pembelajaran sangat menunjukkan sikap positif dengan aspek kreatif, mandiri, rasa ingin tahu, kerja keras, disiplin, shafiyya mengeksplor banyak tentang media yang baru dia temui ini dan selalu disiplin mendengarkan saat medianya menjelaskan proses berlangsungnya metamorphosis pada kupu-kupu atau belalang. Farrel, Umar dan Restya menunjukkan sikap yang sama dengan Shafiyya hanya sedikit berbedanya dari rasa ingin tahu dan kreatif. Mereka tidak banyak mengeksplore karena karakter pemalu serta pendiamnya itu.

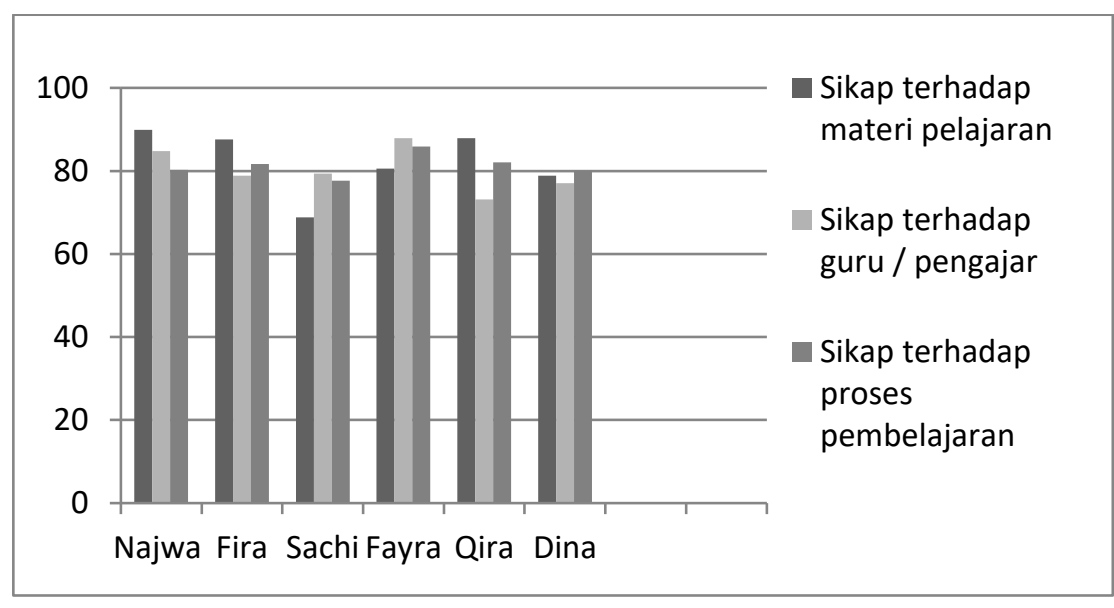

Gambar 6 Grafik Sikap Anak Kelompok Ke- 2

Dari grafik 6 dapat dijelaskan enam orang anak di kelas "Abu Bakar" yang bernama Najwa, Fira, Sachi, Fayra, Qira dan Dina menunjukkan beberapa sikap sedikit berbeda terhadap pembelajaran saat diberikan materi pelajaran metamorphosis serangga melalui pembelajaran multimedia berbasis animasi yakni; 1) Sikap terhadap materi pelajaran, Fira dan Qira yang memiliki karakter mudah bosan, mudah hilang fokus terutama Fira yang sangat suka dengan Gadget langsung menunjukkan sikap baru terbuka dan semangat saat melihat media pembelajarannya, karena menarik dimainkan langsung dan banyak animasinya. Untuk Sachi dan Dina yang memiliki karakter pemalu tetapi masih komunikatif mereka menunjukkan sikap semangat dengan mulai merespon tentang media yang akan digunakannya, dan terakhir Najwa dan Fayra yang sangat aktif, sangat antusias banyak bertanya, semangat, dan ingin segera berlangsung proses belajarnya dengan media yang akan digunakan.

2) Sikap terhadap guru / pengajar, Najwa, Fira, Sachi, Fayra, Qira dan Dina menunjukkan sikap yang sama karena sudah menunjukkan sikap positif dan terbuka maka sikap terhadap guru saat menjelaskan pun mereka semua fokus, menyimak, mendengarkan dan merespon dengan baik. 3) Sikap terhadap proses pembelajaran. Untuk Sachi dan Dina yang memiliki karakter pemalu menunjukakan sikap positif terhadap pembelajaran pada 
aspek mandiri, rasa ingin tahu, kerja keras, disiplin,tetapi belum melakukan imporvisasi dengan media yang sedang dikenalnya. Sedangkan Fira dan Qira yang sedari awal sudah termotivasi dengan media pembelajarannya karena menggunakan gadget lebih banyak menunjukkan sikap positif dengan asep kreatifitas, mandiri dan rasa ingin tahu yang sangat menonjol karena mereka ingin mengeksplore sendiri medianya. Terakhir Najwa dan Fayra yang memang cerdas di kelas menunjukkan sikap positf dengan aspek mandiri, rasa ingin tahu, kerja keras, disiplin.

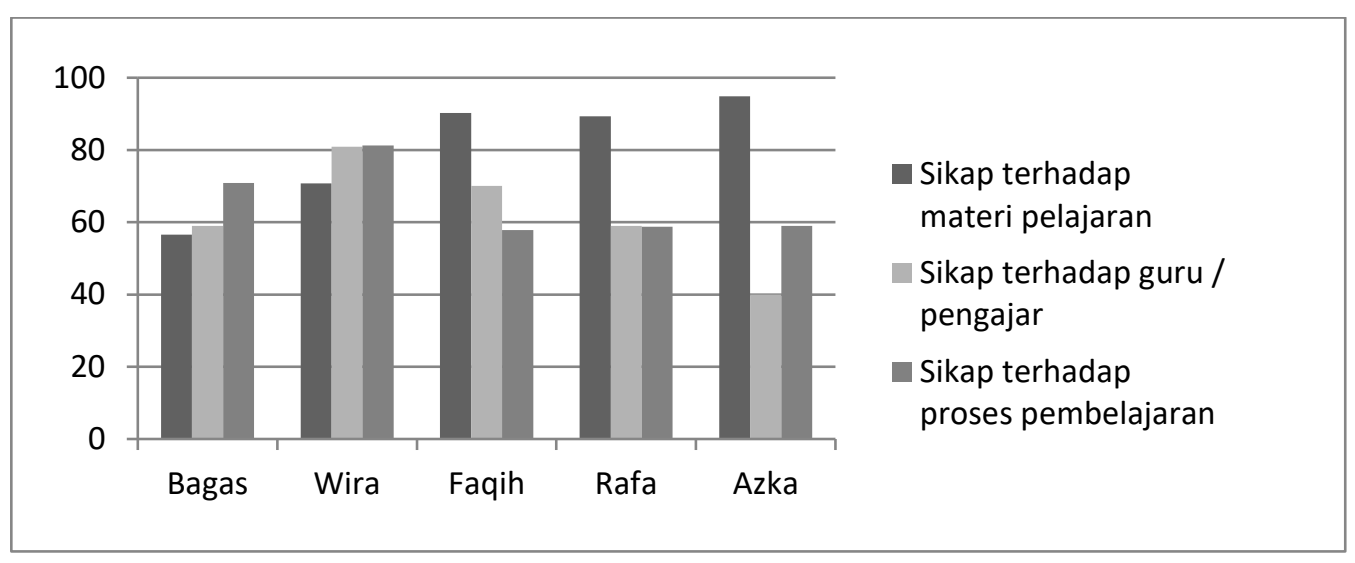

Gambar 7. Grafik Sikap Anak Kelompok Ke- 3

Dari hasil grafik diatas dapat dijelaskan lima orang anak di kelas "Abu Bakar" yang bernama Bagas, Wira, Faqih, Rafa, dan Azka. Menunjukkan beberapa sikap yang cukup berbeda-beda terhadap pembelajaran saat diberikan materi pelajaran metamorphosis serangga melalui pembelajaran multimedia berbasis animasi yakni; 1) Sikap terhadap materi pelajaran, Faqih, Rafa, dan Azka memiliki salah satunya karakter yang serupa yaitu mudah bosan, dan moody, mereka ber-empat langsung membuka diri saat guru mengeluarkan gadget sebagai media pembelajaran terutama saat menggunakan aplikasi yang ada animasinya dan bisa mereka operasikan, sikap positif ditunjukkan disini, sedangkan wira terlihat lebih kalem saat permulaan materi akan dimulai tetapi tetap semangat mengikuti pelajaran meski tidak terlihat seantusias Faqih, Rafa, dan Azka. Sedangkan Bagas tidak merespon apapun menunukkan sikap tertutup dan kurang antusias, Bagas memiliki karakter yang sangat pendiam, pemalu, dan jika ingin berkomunikasi harus tidak di depan banyak orang, maka disini Bagas belum menujukkan sikap positif pada awal pembelajaran.

2) Sikap terhadap guru/pengajar, Faqih, Rafa, dan Azka terlihat kurang merespon guru karena tidak sabar untuk memainkan media aplikasi pembelajarannya terutama yang kurang fokus terhadap gurunya adalah Azka, karena Azka adalah anak yang terlalu aktif tetapi mudah bosan dan mudah hilang fokus jika sudah tertarik pada yang ia sukai, maka Azka menunjukkan paling sikap acuh tak acuh pada gurunya, Wira sendiri yang diawal terlihat lebih kalem dan tidak terlalu menujukkan sikap terbuka, atau responsive terhadap media aplikasi pembelajaran metamorphosis serangga, di sikap terhadap guru Wira sangat menyimak penjelasan guru dan banyak bertanya, fokus pada arahan gurunya, terakhir untuk Bagas mulai mendekati gurunya melakukan pendekatan, ingin menggunakan dan mencoba media aplikasi tetapi malu untuk berkata, Bagas melakukan sikap ingin diperhatikan dan diutamakan kepada gurunya.

3) Sikap terhadap proses pembelajaran, Faqih, Rafa, dan Azka yang paling antusias diawal dan langsung mengoperasikan sendiri media aplikasi pembelajarannya tanpa mau mendengar penjelasannya terlebih dahulu, mereka bertiga lebih senang mengoperasikan gadget dan memainkan tombol di aplikasi tersebut dibanding mendengarkan penjelasan akan proses metamorphosis serangganya. Wira yang paling menunjukkan sikap telaten saat proses pembelajaran berlangsung, memahami yang dijelaskan oleh aplikasi, bertanya jika 
tidak memahami dan menunjukkan sikap positif pembelajaran dengan aspek disiplin, kreatif, mandiri dan rasa ingin tahu. Terakhir Bagas menujukkan sikap positif dengan mau bergabung dengan teman-temannya dan bergantian mengoperasikan aplikasi pembelajaran, Bagas menunjukkan sikap mandiri, toleransi, dan disiplin.

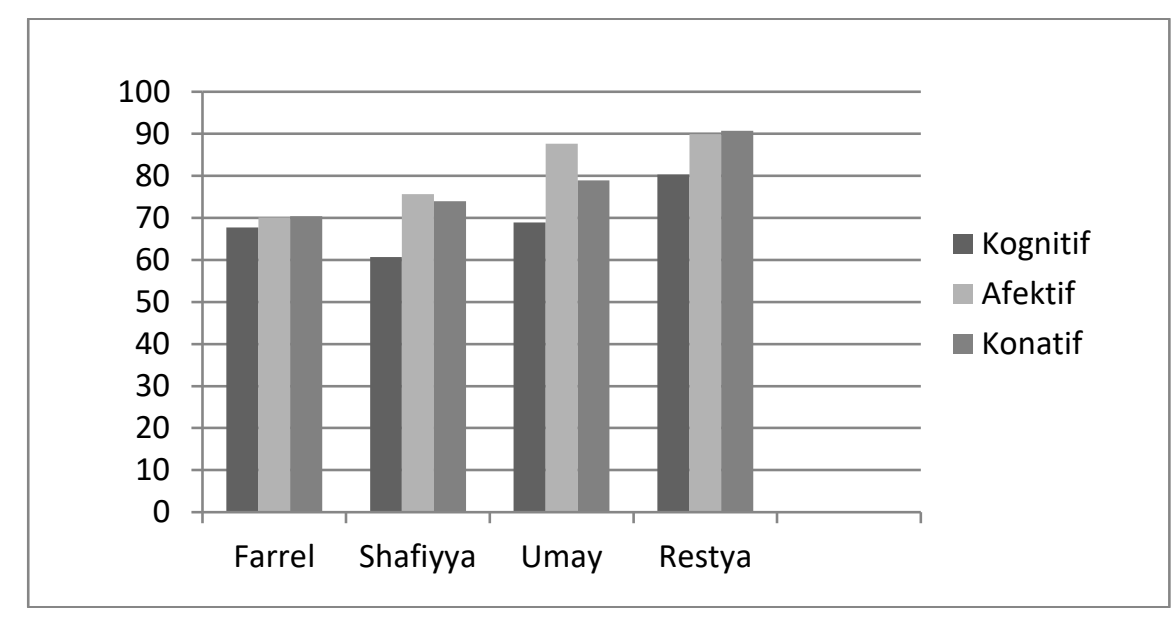

Gambar 8. Grafik Respon Anak Kelompok Ke-1

Dari hasil grafik diatas dapat dijelaskan empat orang anak di kelas "Abu Bakar" yang bernama Farrel, Shafiyya, Umay dan Restya menunjukkan beberapa respon yang terdiri dari Kognitif, Afektif, dan Konatif dalam pembelajaran dengan menggunakan media animasi pada materi pelajaran metamorphosis serangga melalui pembelajaran multimedia berbasis animasi. Mereka menunjukkkan beberapa respon yang beragam, yakni; 1) Respon Kognitif, Farrel, Umar dan Restya cukup menguasai materi dengan adanya respon perubahan keterampilan saat menggunakan media aplikasi dan respon kognitif lainnya dilihat dari penangkapan pesan atau materi penjelasan dari media aplikasi, lalu mereka tangkap dan kemudian cukup banyak dikembangkan melalui pertanyaan sederhana, sedangkan Shafiyya menunjukkan banyak perubahan keterampilan saat menggunakan media aplikasi dan cenderung banyak mengakses banyak informasi dari media aplikasi ini, seperti mulai melka membuat pertanyaan yang sifatnya pengembangan

2) Respon Afektif, Farrel, Shafiyya, Umay dan Restya, menunjukkan respon afektif yang sama yaitu ditunjukkan dengan perasaan senang, gembira, ceria meski untuk Farrel, Umar dan Restya masih ditutupi dengan perasaan malu-malunya. 3) Respon Konatif Farrel, Umay dan Restya cukup terlihat dari perubahan perilakunya karena mereka bertiga cenderung pemalu, terutama masih belum menunjukkan perilaku yang menjadi aktif meski dalam respon afektifnya mereka sangat gembira dengan media pembelajaran yang digunakan. Sedangkan Shafiyya sangat menujukkan perilaku dengan bergerak aktif mengeksplore media pembelajarannya.

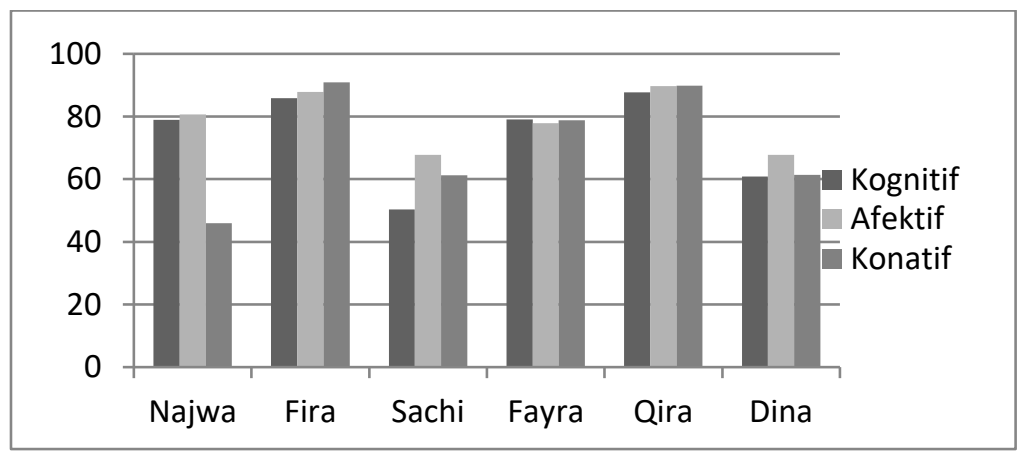

Gambar 9. Grafik Respon Anak Kelompok Ke-2 
Dari hasil grafik diatas dapat dijelaskan enam orang anak di kelas "Abu Bakar" yang bernama Najwa, Fira, Sachi, Fayra, Qira dan Dina menunjukkan beberapa respon yang terdiri dari Kognitif, Afektif, dan Konatif dalam pembelajaran dengan menggunakan media animasi pada materi pelajaran metamorphosis serangga melalui pembelajaran multimedia berbasis animasi. Mereka menunjukkkan beberapa respon beberapa sama dan beberapa lagi berbeda, yakni; 1) Respon Kognitif, Fira dan Qira banyak menangkap informasi dan pesan yang disampikan kemudian mereka olah kembali dengan pertanyaan sederhana, daya imajinasi mereka banyak berkembang saat menggunakan media aplikasi ini. Sama halnya dengan Najwa dan Fayra yang memang memiliki kecerdasan yang baik, mereka cenderung melebarkan informasi yang pernah mereka dapatkan dengan mengkaitkan dengan informasi yang baru mereka dapatkan, pertanyaan yang mereka ajukan lebih berifkat pengembangan. Sedangkan untuk Sachi dan Dina yang pendiam, mereka terlihat memahami meski tidak banyak mengeluarkan pendapat dan mengolah informasi yang mereka dapatkan, hanya diam saja tetapi saat ditanya mereka bisa menjawab.

2) Respon Afektif, Najwa, Fira, Sachi, Fayra, Qira dan Dina menunjukkan emosi yang pada dasarnya sama yaitu senang, gembira, tidak sabar, dan semangat namun seperti Sachi dan Dina bentuk emosinya tida terllau ditunjukkan hanya sebatas senyum saat guru sedang melakukan penjelasan atau saat ditanya. 3) Respon Konatif Najwa, Fira, Fayra, Qira menujukkan perubahan perilaku seperti lebih banyak bergerak dan berekpresi (bertepuk tangan, aktif memainkan gadget yang digunakan, membantu teman yang salah menekan tombol dsb) sedangkan Sachi dan Dina tetap kalem dan tidak begitu menunjukkan perubahan perilaku tetapi saat hanya dengan gurunya mereka menujukkan perubahan perilaku lebih aktif (bertepuk tangan, tertawa lepas,dan banyak bertanya).

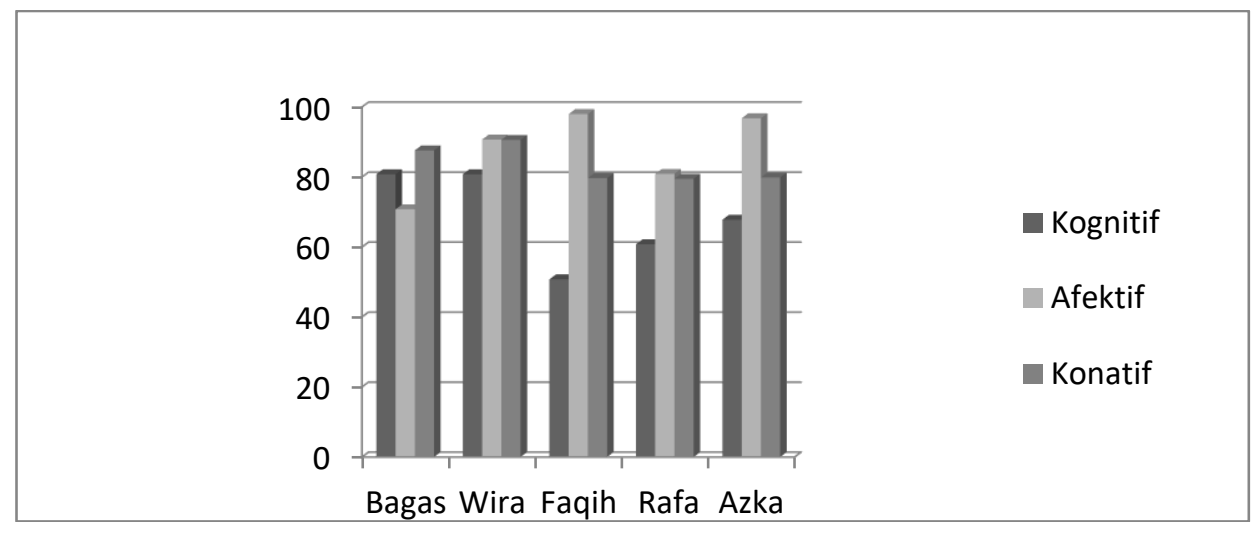

Gambar 10. Grafik Respon Anak Kelompok Ke-3

Dari hasil grafik diatas dapat dijelaskan lima orang anak di kelas "Abu Bakar" yang bernama Bagas, Wira, Faqih, Rafa, dan Azka.menunjukkan beberapa respon yang terdiri dari Kognitif, Afektif, dan Psikomotorik dalam pembelajaran dengan menggunakan media animasi pada materi pelajaran metamorphosis serangga melalui pembelajaran multimedia berbasis animasi. Mereka menunjukkkan beberapa respon yang beragam, yakni; Bagas, Wira, Faqih, Rafa, dan Azka. 1) Respon Kognitif, Wira langsung merespon dengan pemikiran kritis, bertanya hal-hal yang baru di dengar, dan kemudian merangkum informasi yang didapatkan dengan menarik kesimpulan sendiri. Untuk Faqih, Rafa dan Azka tidak terlalu memperhatikan penjelasan hanya seperti terkesima dengan gadget dan aplikasi yang digunakan tidak mendengar informasi, dan tidak bertanya hal-hal mengenai materi. Tetapi saat di wawancara mengenai materi yang sudah mereka lihat, mereka dapat menejlaskan dengan baik dan sangat detail. Terakhir untuk Bagas meski cukup pemalu tapi sedikitsedikit bertanya dan bercerita akan pengalamannya dengan melihat metamorphosis 
serangga melalui televise, dan bagas bisa menjelaskan konsep dasar metamorphosis serangga.

2) Respon Afektif, Bagas, Wira, Faqih, Rafa, dan Azka sama-sama menunjukkan reaksi atau respon emosi yang sama (gembira, bersorak, tepuk tangan,) terutama Faqih, Rafa dan Azka yang paling menunjukkan emosi bahagianya sehingga menjadi cenderung hyperactive. 3) Respon Konatif Faqih, Rafa dan Azka menunjukkan perilaku yang sangat berubah setelah awalnya hyperactive tetapi setelah bosan malah ingin main dan membuka aplikasi lain karena sudah bosan dengan media aplikasi yang diberikan guru. Sedangkan Wira dan Bagas menunjukkan respon konatif pada perubahan perilaku, saling membantu (mengajarkan jika salah satu tidak bisa) dan mengembangkan imajinasi dengan bercerita setelah menonton tanyangan metamorphosis serangga melalui media aplikasi.

Hasil dari penelitian yang sudah dipaparkan diatas menjelaskan mengenai sikap dan respon siswa PAUD saat diberikan pembelajaran inovatif, mengenal metamorphosis serangga menggunakan media animasi. Dari hasil wawancara dengan wali kelas, handayani mengatakan, "Siswa PAUD belum pernah melakukan pembelajaran yang dikonsep seperti game ini, yang bisa dioperasikan langsung oleh siswa, jadi ini adalah hal baru yang pasti akan membuat siswa senang". Dan yang menarik lainnya adalah, pembelajaran mengenal beberapa jenis serangga sambil mengatamati proses metamorfosisnya adalah materi baru di TKIT Irsyadul I'Bad karena materi ini belum disampaikan secara khusus dikarenakan masih mencari media yang menarik dan merangsang siswa untuk bisa menangkap materi ini. Meskipun pembelajaran mengenal jenis jenis binatang masuk pada kurikulum yang digunakan TKIT Irsyadul I'bad,Karena TKIT Irsyadul I'bad menggunakan Kurikulum K-13 dikombinasikan dengan kurikulum JSIT (Jaringan Sekolah Islam Terpadu). Biasanya pengenalan jenis-jenis binatang akan disesuaikan oleh guru menyesuaikan dengan metode dan media yang paling menarik untuk digunakan, dan mengenal jenis serangga untuk pengenalan serangga sendiri masuk dalam Tema : Binatang dengan Sub tema : Binatang Bersayap berikut dengan metamorfosisnya menjadi materi terpilih karena metode dan media inovatif dan menarik untuk digunakan pada kelas Abu Bakar TKIT Irsyadul I'bad.

\section{Sikap Siswa PAUD menggunakan media pembelajaran baru}

Dalam langkah awal penelitian dilakukan penjajakan respon peserta menggunakan tehnik perkenalan melalui Zoom Meeting, hal ini peneliti lakukan untuk menilai respon awal siswa dan menjajaki karakter siswa. Selanjutnya pembelajaran dilakukan secara home visit. Peneliti dan pengajar mengunjungi rumah peserta yang sudah di kelompokkan, saat pembelajaran secara home visit memang membawa suasana yang berbeda, siswa lebih merasakan suasana informal, situasi ini menjadi pendukung dalam membentuk mood siswa seperti halnya dengan yang dikatakan oleh seorang tokoh behavioristic Gagne dalam (Sudjana, 2010) bahwa dalam aliran behavioristik kegiatan belajar terjadi karena adanya kondisi/stimulasi dari lingkungan. Kegiatan belajar merupakan respon/reaksi terhadap kondisi/stimulus lingkungannya. Belajar tidaknya seseorang tergantung pada faktor kondisional dari lingkungan. Lingkungan dapat berupa lingkungan keluarga, masyarakat maupun lingkungan sekolah. Lingkungan sekolah terdiri dari guru, media pembelajaran, buku teks, kurikulum, teman kelas, peraturan sekolah maupun sumbersumber belajar lainnya, ini menegaskan dengan keadaan lingkungan yang membuat siswa semakin nyaman maka belajar akan semakin efektif. Kemudian saat home visit ini metodenya adalah mengulas kembali perkenalan yang awalnya sudah dilakukan dalam zoom meeting. 

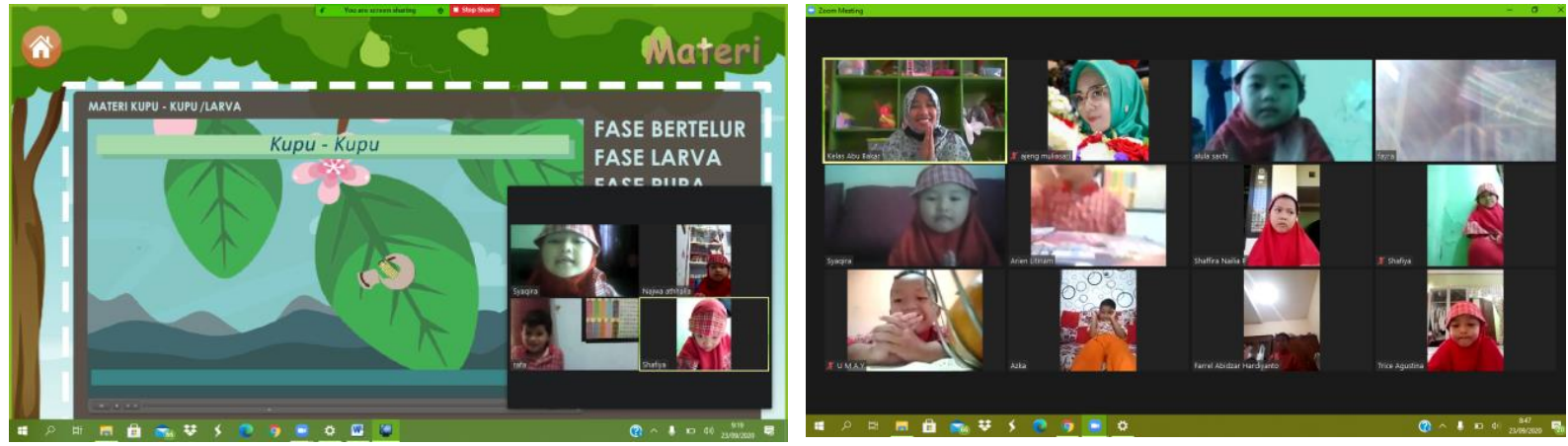

\section{Gambar 11. Pengenalan awal pembelajaran dalam Zoom Meeting}

Siswa yang ada dikelas Abu Bakar ini berusia 5 tahun. Dengan perilaku kognitif, konatif dan afektif yang beragam. Proses yang dilakukan guru dalam pembelajaran mengenal metamorphosis serangga melalui media animasi berbasis CAI pada siswa dilakukan dengan beberapa tahap, yaitu: (1) Proses pengenalan untuk melihat respon awal siswa, pengenalan ini dilakukan melalui zoom meeting karena saat itu sekolah belum diperbolehkan masuk, pada pengenalan awal ini respon siswa sangat baik karena banyak pertanyaan menarik yang mereka lontarkan. (2) Proses pembelajaran secara langsung atau tatap muka dilakukan melalui home visit yang sudah dibagi ke dalam 3 kelompok, masingmasing berjumlah 4-6 orang. Pada proses ini yang sudah peneliti paparkan hasilnya diatas menunjukkan dari ke-3 kelompok memiliki sikap yang bagus terhadap pembelajaran mengenal metamorphosis serangga ini, meskipun tetap masih ada sikap dan respon yang menjadi catatan peneliti. (3). Pada saat proses pembelajaran ini pengajar fokus membimbing siswa karena ini merupkan media baru yang digunakan siswa, dan pengajar melakukan kegiatan variatif dengan mengajak siswa bernyanyi "kupu-kupu yang lucu" dan juga mengajak siswa menari tarian "Kupu-Kupu". (4) Setelah melakukan pemberian materi, dalam aplikasi media animasi pengenalan serangga berbasis CAI ini ada test mengenai pemahaman siswa terhadap materi, dan test ini membantu penilaian aspek dari respon kognitif, konatif, dan afektif siswa terutama yang terlihat adalah respon kognitif siswa yang selain lebih mandiri dalam belajar lalu siswa lebih fokus untuk meneliti dan mengulas materi yang disampaikan seperti yang dikatakan oleh Gagne (Surya, 2015) menyebutkan bahwa "strategi kognitif merupakan salah satu hasil pembelajaran yang paling penting berupa keterampilan dalam mengatur proses internal dalam penghampiran, pemahaman, mengingat, dan berpikir". Hasil dari pencapaian respon kognitif siswa dibuktikan dengan, saat pengerjaan test siswa selain diulas materi yang sudah diberikan. Selain itu dari kegiatan test yang dilakukan siswa untuk menguji materi yang sudah disampaikan siswa menunjukkan beberapa keterampilan, seperti siswa membantu temannya, bekerjasama dengan teman,sikap jujur dan percaya diri dalam mengerjakan soal latihan, bahkan respon konatif saat mengapresiasi atau memberi semangat teman yang belum lancar.

Dari hasil analisa umum yang sudah dipaparkan dan dibahas peneliti, ada beberapa analisa khusus dan catatan khusus peneliti setelah mengamati dan mewawancarai siswa dalam belajar mengenal metamorphosis serangga melalui media animasi berbasis CAI. Berikut analisa dan catatan khusus peneliti. (1) Beberapa siswa dikelas Abu Bakar memiliki respon Koginitif yang tinggi, seperti Shafiyya, Wira, Najwa dan Fayra, ini membawa siswa yang lain yang malu bertanya, yang masih bingung mendapat informasi dari temannya semacam konsep tutor sebaya, karena Shafiyya, Wira, Najwa dan Fayra selain pintar, mereka juga aktif dan memiliki respon afektif yang baik.

Selanjutnya poin analisa dan catatan peneliti yang ke (2) adalah pada saat pertemuan di minggu ke-1 dengan kelompok pertama, yaitu Farrel, Shafiyya, Umay dan Restya, terlihat memang masih ada sikap dan respon belum terbuka dari Farrel, Umay dan Restya ini menjadi analisa tersendiri peneliti karena peneliti berasumsi beberapa siswa PAUD belum 
terlalu terampil memegang gadget sehingga peneliti menghawatirkan, ini menjadi kendala yang mana beberapa siswa yang belum terampil dengan gadget menjadi tidak Percaya Diri saat akan belajar. Namun asumsi peneliti tidak terjadi dengan perubahan sikap Farrel, Umay dan Restya. Perubahan itu terjadi dengan menggunakan beberapa trik dari pengajar yaitu, mencoba meminta tolong menyalakan gadgetnya kemudian meminta siswa membuka aplikasi media animasi dan pada saat tampilan utama terbuka yaitu tampilan untuk memasukkan nama, guru membantu mengeja nama siswa dan siswa mengetik satu persatu huruf yang sesuai dengan namanya. ini dilakukan sebagai upaya agar kepercayaan diri siswa PAUD muncul bahwa belajar dengan gadget tidak menakutkan. Penanggulangan perasaan tidak nyaman yang dirasakan oleh beberapa siswa saat belajar menggunakan media baru harus menjadi perhatian pengajar dan cepat diatasi agar menumbuhkan sikap keberanian dan percaya diri pada siswa PAUD untuk belajar menggunakan media baru apapun.

Analisa dan catatan peneliti yang ke (3) Penggunaan media animasi berbasis CAI tentunya akan melibatkan gadget menjadi alat dalam melakukan pembelajaran, ada catatan tersendiri dari peneliti akan gadget yang digunakan untuk belajar, hal ini dapat dilihat dari beberapa sikap yang muncul dari siswa yang menjadi catatan tersendiri peneliti, yaitu pada kelompok ke-3 Faqih, Rafa dan Azka, rasa antusias yang terlalu tinggi membuat mereka mengabaikan sikap-sikap yang seharusnya dipatuhi saat belajar, dan sikap yang seharusnya ditunjukkan kepada guru, mendengarkan guru mengamati guru, bahkan merespon guru, tetapi sikap -sikap itu tidak muncul dari Faqih, Rafa dan Azka karena fokus mereka adalah memainkan gadget. Saat sikap seperti ini muncul guru kelas Abu Bakar, melalukan Tarik ulur alat belajar yang digunakan (Gadget) hal ini dilakukan agar siswa belajar fokus tidak pada satu arah saja tetapi fokus juga terhadap penjelasan guru, sekaligus ini membantu guru untuk menilai sejuah mana media animasi dalam mengenal metamorphosis serangga ini sampai kepada pemahaman siswa hal ini seperti yang dalam jurnal prosiding berjudul "Penggunaan Gadget untuk menciptakan pembelajaran efektif" yang dilakukan oleh (Mahfud \& Wulansari, 2018) bahwa pemanfaatan media pembelajaran berupa gadget dalam pembelajaran perlu mengingat beberapa pertimbangan baik positif maupun negatif. Pada dampak positif penggunaan gadget dalam pembelajaran adalah akan memudahkan siswa memperoleh informasi dengan cepat dan simpel. Gadget juga dianggap sebagai "teman" saat ini bagi masyarakat khususnya siswa dilingkungan sekolah, gadget dilibatkan dalam pembelajaran. Maka diharapkan akan memotivasi siswa dalam memperoleh bahan ajar dan pembelajaran menjadi lebih menyenangkan. Tidak hanya dampak positif yang ditimbulkan dalam gadget, dampak negatif dari media pengguna gadget juga diperlu diperhatikan. Penggunaan waktu yang berlebihan dalam penggunaan gadget, dapat membuat siswa enggan belajar dengan buku dan tidak jarang disalah gunakan penggunaannya. Dengan demikian, dampak ini perlu diperhatikan dan diperkenalkan oleh semua pihak kepada siswa, sehingga siswa dapat mengetahui dampak positif dan negatif dari penggunaan gadget dalam pembelajaran.

Maka dari hasil penelitian diatas memang belajar dengan gadget pengajar perlu menggunakan beberapa metode atau tehnik, beberapa metode atau tehnik yang dilakukan adalah dengan metode tanya jawab sambil siswa belajar mengoperasikan secara mandiri. Namun keunikan lain adalah pada saat Faqih, Rafa dan Azka meski menunjukkan sikap tidak fokus pada guru dan lebih kepada gadget namun saat ditanya mengenai materi mereka cepat dan tepat menanggapinya. Hasil temuan Asmariani (2016) bahwa penggunaan media akan lebih menjamin terjadinya pemahaman dan retensi yang lebih baik terhadap isi pelajaran. Media pembelajaran juga mampu membangkitkan dan membawa murid ke dalam suasana senang dan gembira, ada keterlibatan emosional dan mental. Penggunaan media mempengaruhi perkembangan anak. Conroh media yang digunakan diantaranya; Diorama (Hasanah \& Muryanti, 2019), media ppan semat (Laily et al., 2019), grafis (Purwani et al., 2019) dan lain sebagainya. 
Beberapa poin analisa dan catatan umum dan khusus peneliti telah dipaparkan diatas. Maka selanjutnya peneliti memberikan benang merah dari pembahasan yang sudah peneliti uraikan. Berdasarkan hasil penelitian yang telah dilakukan, dapat diketahui penggunaan media animasi berbasis CAI untuk mengenalkan proses metamorphosis serangga (Kupu-kupu dan Belalang) pada siswa PAUD adalah hal yang inovatif dan merangsang semangat belajar siswa PAUD, seperti yang dikatakan oleh (Ariani, $\mathrm{N}$ dan Haryanto, 2010) bahwa multimedia interaktif adalah suatu multimedia yang dilengkapi alat pengontrol yang dapat dioperasikan oleh pengguna, sehingga pengguna dapat memilih apa yang hendak dipelajarinya. Hal ini dibuktikan dari sikap awal saat memulai pembelajaran, siswa-siswa yang memiliki karakter aktif dan selalu ingin tahu seperti yang aktiv dan membuktikan bahwa media animasi berbasis CAI dimana siswa bisa mengoperasikan secara mandiri sekaligus siswa bisa memilih sendiri apa yang ingin dipelajarinya, proses pembelajaran ini membangun sikap positif yang baik yang dapat dilihat dari awal pembelajaran, sikap terhadap guru dan saat proses pembelajaran, begitu pula dengan perkembangan kognitif siswa yang dapat dilihat dari keingintahuan siswa terhadap media yang digunakan dan materi yang diajarkan.

\section{SIMPULAN}

Pengenalan serangga beserta proses metamorfosisnya untuk anak PAUD adalah pengetahuan dasar yang penting untuk dipahami anak PAUD, terutama serangga yang sering dilihat dan dekat dengan kehidupan anak PAUD seperti Kupu-kupu dan Belalang. Pembelajaran dengan media animasi berbasis CAI ini selain menyenangkan dan menambah semangat belajar anak karena melibatkan gadget sebagai alat pembelajarannya, membuat anak PAUD lebih terampil dengan tekhnologi digital dan memancing aspek kognitif, konatif, maupun afektif anak menjadi lebih terasah dan terampil.

\section{UCAPAN TERIMA KASIH}

Penelitian ini didanai sepenuhnya oleh Direktorat Riset dan Pengabdian Masyarakat Kementrian Riset dan Teknologi/Badan Riset dan Nasional pada skema Penelitian Dosen Pemula (PDP) tahun 2020. Dan juga terimakasih kepada Jurnal Obsesi : Jurnal Pendidikan Anak Usia Dini yang telah memberikan masukan dalam penulisan artikel ini

\section{DAFTAR PUSTAKA}

Ariani, N dan Haryanto, D. (2010). Pembelajaran Multimedia di Sekolah. Prestasi Pustaka.

Asmariani, A. (2016). Konsep Media Pembelajaran Paud. Al-Afkar: Jurnal Keislaman \& Peradaban, 5(1). https://doi.org/10.28944/afkar.v5i1.108

Azwar S. (2011). Sikap Manusia: Teori dan Pengukurannya. Pustaka Pelajar.

Dhuhita, W. M. P. (2018). Penerapan Multimedia Pembelajaran Pada Paud Puspasari. Prosiding Seminar Hasil Pengabdian. http://ojs.amikom.ac.id/index.php/semhasabdimas/article/view/2286

Dwanda Putra Lovandri, I. (2015). Pengembangan Multimedia Pembelajaran Interaktif Mengenal Angka dan Huruf Anak Usia Dini. Inovasi Tekhnologi Pendidikan., 02((02)), 169-178. https://doi.org/10.21831/tp.v2i2.7607

Eka Septi, H. (2016). Animasi Interaktif Pengenalan Hewan Khas Pulau Indonesia Berbasis Andorid Pada TK Kupu-Kupu Mungil Bekasi. Jakarta. Teknik Komputer BSI., 02((01)). https://doi.org/10.31294/jtk.v2i1.358

Eko Putro Widoyoko. (n.d.). Penilaian Hasil Pembelajaran di Sekolah.

Faris Ahmad, A. F. (2016). Rancangan Pembelajaran Interaktif Alfabeth Pada Anak Usia Dini. Teknik Komputer BSI, 02((01)). https:// doi.org/10.31294/jtk.v2i1.363

Hasanah, A., \& Muryanti, E. (2019). Pengaruh Penggunaan Media Diorama terhadap 
Perkembangan Kemampuan Motorik Halus Anak Usia Dini. Aulad: Journal on Early Childhood, 2(2), 1-7. https:/ / doi.org/10.31004/aulad.v2i2.29

Himmah Taulany, Lisa Virdinarti Putra, I. S. W. (2020). Media Tangram Geometri “Let's Be Healthy" Berbasis Android untuk Meningkatkan Kemampuan Berpikir Geometri Anak Usia Dini. Obsesi, 4(1), 676-685. https:/ / doi.org/10.31004/obsesi.v4i2.365

James W.Truman. (2019). The Evolution of Insect Metamorphosis. Current Biology, 29(23), R1252-R1268. https:// doi.org/10.1016/j.cub.2019.10.009

Kholis Abdul. Herawati. (2015). Animasi Interaktif Pembelajaran Tajwid Pada Taman Qur'an Anak (TQA) Al- Washilah Cirebon. Jakarta. Teknik Komputer BSI., 01((02)). https:// doi.org/10.31294/jtk.v1i2.247

Laily, A., Jalal, F., \& Karnadi, K. (2019). Peningkatan Kemampuan Konsep Matematika Awal Anak Usia 4-5 Tahun melalui Media Papan Semat. Jurnal Obsesi : Jurnal Pendidikan Anak Usia Dini, 3(2), 396. https:// doi.org/10.31004/obsesi.v3i2.214

Lalu Teguh Jiwandanu. (n.d.). Urgensi PAUD dalam Era Digital. Life Journey Teguh Jiwandanu.

Mahfud, M. N., \& Wulansari, A. (2018). Penggunaan Gadget untuk Menciptakan Pembelajaran yang Efektif. Seminar Nasional Pendidikan, 58-63.

Maulana, G. A. (2018). Pembangunan aplikasi pembelajaran metamorfosis serangga berbasis multimedia. Universitas Pasundan.

Menteri, P. P. N. (2013). Kurikulum 2013 Pendidikan Anak Usia Dini No.146 Tahun 2014.

Nasution, R. H., Hapidin, \& Fridani, L. (2020). Pengaruh Pembelajaran ICT dan Minat Belajar terhadap Kesiapan Membaca Anak Usia Dini. Jurnal Obsesi: Jurnal Pendidikan Anak Usia Dini, 4(2), 733-746. https://doi.org/10.31004/obsesi.v4i1.326

Nofiadi, S., Listyorini, T., \& Susanto, A. (2017). Animasi Metamorfosis Kupu-Kupu. DSimetris, 8(1), 299-308. https://doi.org/doi.org/10.24176/simet.v8i1.990

Panjaitan, N. Q., Yetti, E., \& Nurani, Y. (2020). Pengaruh Media Pembelajaran Digital Animasi dan Kepercayaan Diri terhadap Hasil Belajar Pendidikan Agama Islam Anak. Jurnal Obsesi: Jurnal Pendidikan Anak Usia Dini, 4(2), 588. https:// doi.org/10.31004/obsesi.v4i2.404

Pekka Mertala. (2019). Teachers' beliefs about technology integration in early childhood education: A meta-ethnographical synthesis of qualitative research. Computers in Human Behavior, 101, 334-349. https://doi.org/10.1016/j.chb.2019.08.003

Purwani, A., Fridani, L., \& Fahrurrozi, F. (2019). Pengembangan Media Grafis untuk Meningkatkan Siaga Bencana Banjir. Jurnal Obsesi : Jurnal Pendidikan Anak Usia Dini, 3(1), 55. https:// doi.org/10.31004/obsesi.v3i1.142

Rahman, T., Mulyana, E. H., \& Wendah, S. (2018). Peningkatan pemahaman tentang metamorfosis melalui media gambar seri di kelompok B TK negeri pembina kota tasikmalaya. Jurnal PAUD Agapedia, 2(2).

Rakhmat, J. (2013). Psikologi Komunikasi. PT. Remaja Rosda Karya.

sadat, rosman. (2019). Pengaruh Model Pembelajaran Self Regulated Learning pada Mata Pelajaran Biologi terhadap Literasi Sains dan Sikap Ilmiah Siswa Kelas X SMAN 5 Kendari Sulawesi Tenggara. Bioedusiana, 4(2), 1-8. https://doi.org/10.34289/285227

Sudjana, N. (2010). Dasar-dasar Proses Belajar. In Bandung: Sinar Baru. Sinar Baru.

Surya. (2015). Strategi Kognitif dalam Proses Pembelajaran. Alfabeta.

Sutarjo Adi Susilo. (2014). Pembelajaran Nilai Karakter. Rajawali Pers.

Wang Di, Z. R. (2012). The Analysis on Current Situation and Development Trend of Experimental Animation in Our Country. Energy Procedia, 17(B), 1314-1318. https:// doi.org/doi.org/10.1016/j.egypro.2012.02.245 